\title{
THE CONCEPT OF THE TOURISM ENTERPRISE INNOVATION ANALYSIS
}

\author{
LESZEK KOZIOŁ, ${ }^{1}$ ANNA KARAŜ́ ${ }^{2}$ \\ ${ }^{1}$ Univeristy of Economics in Krakow, POLAND \\ e-mail: kozioll@interia.pl \\ ${ }^{2}$ Malopolska School of Economics in Tarnow, POLAND \\ e-mail: amikrut@mwse.edu.pl
}

KEYWORDS ABSTRACT

innovations, potential for innovation, innovation capability, tourism businesses

The aim of the paper is to present the analysis concept focused on the evaluation of company innovation capability. The innovative enterprises potential in tourism industry is the evaluation starting point, with regard to the innovation system of a company. An important research tool is the analysis of the relationship between resources and capabilities showing a causal relationship between these categories. The qualitative measurement procedure of the enterprise innovation capability has been described in the article and steps to verify that capability have been provided. The further part of this article presents the results of the empirical research on innovation of 12 tourist companies. It has been demonstrated that the key determinants of this ability are the employee as well as managerial competences in the frames of innovations, cooperation with customers and collaborators in terms of knowledge, innovation-oriented organizational culture and the use of IT tools. In the light of the given, own, empirical research results and also the predecessors' research results, it can be presumed that companies compete with one another through the created innovation as well as their innovative capability. The innovative capability assessment may be useful in determining the competitive and strategic enterprises position in a given sector.

\section{Introduction}

The presented concept assumes that innovation is any beneficial, creative and original change in different areas of the organization. The change that brings novelty and progress in relation to the positively assessed status quo, in the light of the criteria for the organization effectiveness. In contrast, the innovation (innovation system) means both the innovation potential of the company and its innovation capability. As a refinement of the concept, the C.M Hall and A.M Williams 
thesis have been adopted. According to it, the innovation system is defined as the organizing and positioning of actors, i.e. companies and other organizations that participate in generating, diffusion and use of novelties (new knowledge) useful and bringing economic benefits the manufacturing process. $^{1}$

It should be noted that such a presentation of the essence of innovation and enterprise innovativeness is based on an interdisciplinary and multi-faceted approach, engaging the causal impact of various phenomena and processes for innovation. However, the research on organizations innovativeness system requires a new perspective on the subject. Namely, the analysis of the field extension of the problems of innovativeness understood as the potential for innovation on the one hand, and at the same time, of the innovative activity issues, i.e. the innovation capability, invention and diffusion of innovation on the other hand.

The innovative potential of enterprises has been defined as a set of socio-economic characteristics, shaped in the development of the company, which are the basis for his innovative activity. In particular, these are the developed resources such as tools, processes, structures, relationships and other factors inherent in the company.

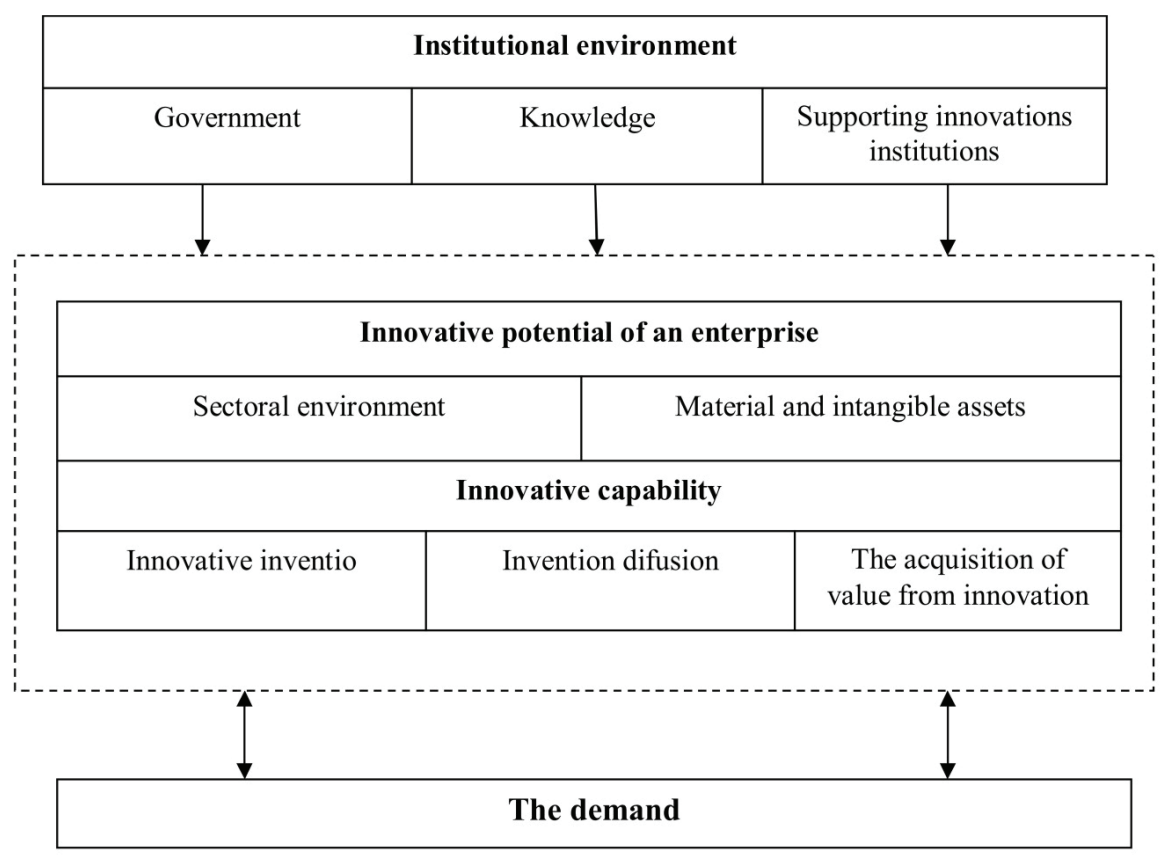

Figure 1. Innovative potential and innovative capability within the system of innovativeness

Source: L. Kozioł, A. Wojtowicz, A. Karas, Postępowanie badawcze ewaluacji zdolności innowacyjnej przedsiębiorstwa, in: eds. Stabilność organizacji we wspótczesnej gospodarce, M. Cisek, T. Nowogródzka, Studio Emka, Warszawa 2014, pp. $48-57$.

${ }^{1}$ C.M. Hall, A.M. Williams, Tourism and Innovation, Routledge, New York 2008, p. 24. 
The innovative potential is also determined by the environment sector, mainly the market and that is the company with customers, competitors, suppliers and cooperators (including in particular the relationships that link the company with its key stakeholders), because the innovations particularly appear or are discovered in contact with the market. The institutional environment has a significant impact on this potential, in particular the development of new technologies, social changes, change of the market shape, legislative regulations, and more.

The effectiveness of the company in terms of innovation (innovation performance) is determined by the resources developed in the past (potential for innovation), as well as the appropriate methods, skills and their current use (innovative capability). The authors dealing with this subject explain that it is the ability to create something new or to introduce significant changes, acting in a way that exploits the ability. ${ }^{2}$

While presenting the innovative capability issue it is worth emphasizing the importance of knowledge in its creation. It is, above all, the knowledge accumulated by the company in the course of organizational learning, the knowledge of deliberate creation which allows the effective use of innovative potential (resources) for its innovation activity, knowledge and knowledge management included in the patterns and economic pragmatism which is the major causative agent of progress and favorable changes, it is the company innovative capability. ${ }^{3}$ Modern organizations, however, are still looking for significant and lasting links between knowledge, knowledge management and innovative capability, and even attempts are being made to identify and determine the impact of various forms of information and knowledge on the kind of innovation.

The issues described in the introduction are the basis for further analysis presented in this article, and in particular the concept of a description of the innovation and the innovation process, identification and characterization of potential determinants of innovation (innovation potential) of the Little Poland region tourism enterprises, the assessment of the innovation (innovation capability), and the assessment of enterprise innovation system (innovation performance).

\section{Concept thesis and stages of pesearch}

The cognitive aim (methodology) of this article is to present the concept of the analysis focused on the innovative capability of a tourist company evaluation. The starting point for the estimation is the innovative potential of the surveyed enterprises, while the reference is an enterprise innovativeness system. The practical aim of this thesis is to present the results of empirical research.

The basic problem that is described in this paper, is an identification of the innovation potential determinants and assessment of their effectiveness as a prerequisite for the development of the innovative capacity and the support of tourist enterprises innovativeness. The objective of

\footnotetext{
2 M.F. Hiliami, T. Ramayah, Y. Mustapha, S. Pavanchlik, Product and Process Innovativeness: Evidence from Malaysian SME's, "European Journal of Social Science" 2010, Vol. 16, p. 557.

${ }^{3}$ Defining this issue more specifically, it is assumed that knowledge is the ability to take action, in particular innovative activity [cf. T.H. Davenport, L. Prusak, 2000, pp. 185-199]. In the companies' practice the creating of knowledge is equated with innovation [cf. R. Pace, A. Dipace, 2014, pp. 185-199, M. Zastempowski, 2013, pp. 68-75, M. Pichlak, 2012, pp. 128-135].
} 
the research presented in this way required to develop the concept of diagnostic analysis aimed at evaluating the potential and innovative capability of the company. An important research tool is the analysis of the relationship between resources and capabilities, which shows a cause and effect relationship between these categories. In the thesis, the following concepts are assumed:

- Innovative capability is a function and at the same time the criterion of an innovation companies evaluation system, as well as the possibility of stimulating innovative activities.

- Innovative capability can be considered partially (which correspond to the determinants of this ability), or it can be recognized as an aggregate form for the company or the whole branch of industry.

During the research procedure the following steps have been distinguished :

1. Identification of the subject and scope of analysis.

2 Formulation of dimensions (criteria) of the innovation potential.

3. The quality level of innovative capabilities measurement

4. Categorization of enterprises.

5. Verification

\section{Identificeation of the subject and scope of analysis}

In order to assess the innovation capability of enterprises the surveys, attended by 316 business entities from the Little Poland region, have been conducted. Among all the respondents 12 companies operating in the tourism industry have been distinguished. The study was conducted in the years 2012-2013.

The questionnaire includes the questions about the general characteristics of the company, identifying the number and innovation, forms of cooperation between enterprises in the field of innovation and knowledge, changes in the market and increased competition that affected the competitiveness of tourism enterprises, questions about the description of the significance of legal regulations and the most significant features of the enterprise - determinants of its innovation - i.e. tools, processes, relationships, competence of development and use of innovations.

In light of the above remarks, the innovative capability has been analyzed in an aggregate form. The aggregate innovative capability is the synthetic estimation criterion of how mature the innovation potential of the company (of the given system) is, which merges partial figures into a single formula for the innovative capability presented in Table 1.

The conducted analyzes show that surveyed companies belong to the SME sector. In the case of more than $40 \%$ of the companies, they employ less than 50 employees. Most of them are hotel and catering companies, $17 \%$ are sports and recreational companies and $8 \%$ transport companies. The analyzed companies operate in the international or regional markets (equally $42 \%$ both), 16\% are companies operating on a national scale. 
The innovation potential determinants are identified based on various sources of information. With the use of the analysis of the influence factors, from a range of environmental variables and the organization's resources, five determinants which have a significant impact on business innovation have been distinguished.

\section{Wording of innovation potential dimensions (criteria)}

The issue of the innovative capability development of the company is seen in two distinctive dimensions: innovation potential and the innovative capability, consisting mainly of creating new products (innovation creativity) and applying it in practice (diffusion of innovation). Correlates of various dimensions are the spheres of change and development, i.e. the areas which contain

Table 1. Determinants of the development of the capacity of firms

\begin{tabular}{|c|c|c|c|}
\hline \multirow[b]{2}{*}{ Determinants } & \multirow[b]{2}{*}{ Components } & \multicolumn{2}{|c|}{ Number of indications } \\
\hline & & $\begin{array}{c}\text { number } \\
\text { of enterprises }\end{array}$ & $\begin{array}{c}\text { number } \\
\text { of enterprises in \% }\end{array}$ \\
\hline \multirow{5}{*}{$\begin{array}{l}\text { Managerial and employee } \\
\text { competences }\end{array}$} & Knowledge of foreign languages & 11 & 92 \\
\hline & Training time & 8 & 67 \\
\hline & Investments in training & 7 & 58 \\
\hline & Ability to use modern technology & 4 & 33 \\
\hline & Level of education & - & - \\
\hline \multirow{5}{*}{ Modernity of infrastructure } & Methods of communication in a company & 7 & 58 \\
\hline & Utilization of infrastructure & 7 & 58 \\
\hline & System layout & 1 & 8 \\
\hline & Database & - & - \\
\hline & Type of IT system & - & - \\
\hline \multirow{8}{*}{ Work organization } & Culture of innovation & 11 & 92 \\
\hline & Infrastructure to support the decision making process & 5 & 42 \\
\hline & Rewarding for innovation & 4 & 33 \\
\hline & Forms of work organization & 4 & 33 \\
\hline & Types of employment contracts & 1 & 8 \\
\hline & Group problem solving & - & - \\
\hline & The existence of R\&D department & - & - \\
\hline & Internal links between workstations & - & - \\
\hline \multirow{4}{*}{$\begin{array}{l}\text { External cooperation } \\
\text { on innovation (knowledge } \\
\text { alliances) }\end{array}$} & Collaboration with other entities & 12 & 100 \\
\hline & The number of cooperants & 12 & 100 \\
\hline & The frames of cooperation & 5 & 42 \\
\hline & Sources of knowledge & 3 & 25 \\
\hline \multirow{4}{*}{ Knowledge protection } & Knowledge protection clauses & 4 & 33 \\
\hline & Access to innovation & 1 & 8 \\
\hline & Database dates & 1 & 8 \\
\hline & Legal forms of protection & 1 & 8 \\
\hline
\end{tabular}

Source: own research. 
a specific reference to the embodiment innovation. Table 1 shows the determinants of the changes sphere and the potential development of innovative enterprises. ${ }^{4}$

The determinants of the change sphere and the innovation ability development of enterprises are those among the innovation potential determinants, which are efficiently and effectively used to create innovation. In addition, and perhaps most of all, in this area, the characteristic class is innovations whose detailed figures are: types and the number of innovation, e.g. product innovations, process innovations, organizational and marketing innovations, business innovations as well as results achieved in the short and long term perspective, and others.

\section{Measuring the quality level of innovative capabilities}

Measuring the innovative capacity quality level requires to be verified. The rating assessment is to indicate to what extent the company is achieving its goals (functions) and meets certain requirements. The verification assessment formula is expressed by the relation of the factual state of the enterprise (S) to the pattern (M) - model state. Defined in such a way, the assessment rate is also a tool that checks the standardization of evaluation criteria by which the aggregate assessment is possible.

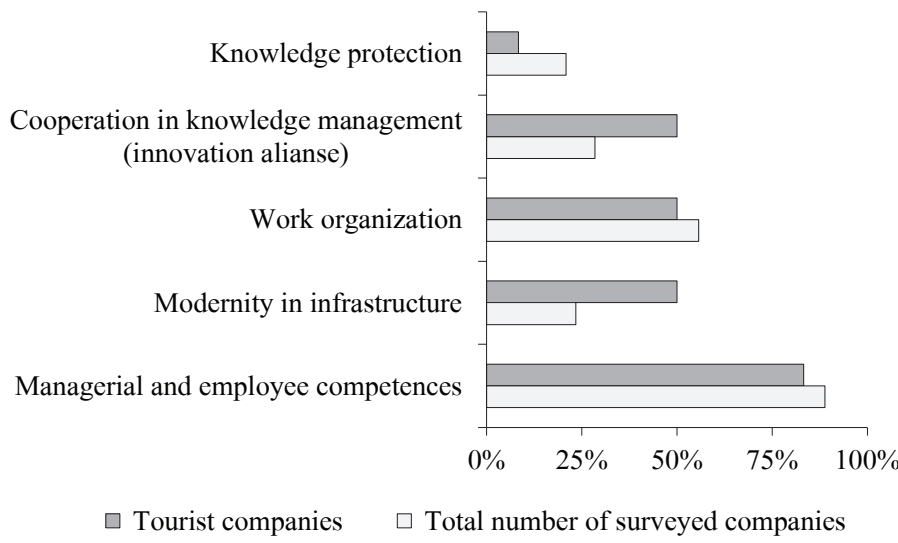

Figure 2. Determinants of enterprises innovation ability in the tourism industry on the background of the determinants of innovation capability of the Little Poland Region entities

Source: own research.

${ }^{4}$ The presented set of innovation potential determinants has been separated, among many environmental variables and the organization's resources, by means of the factors of influence analysis. Those whose significant cause and effect relationships have occurred and will occur in the future have been indicated. In the process of identifying them a number of different sources of information are used. Those relating to the environment include: statistics, special reports, test results of predecessors and expert opinions. With regard to the resources of an organization, the opinions of managers and specialists from surveyed enterprises are used. The collected comments and statements are the basis for the selection of the determinants of innovation potential of the company. 
In the process of evaluation the innovative capability, the normalization of the aggregation point type is used. It is assumed that the standard score for each sub-criterion of assessment (component) is 1 (positive scale) and 0 (negative scale). If the total score of most sub-criterion (components) of the given determinant is positive (i.e. positive scale 1), the qualification of the determinants of enterprise innovation potential is positive.

According to the adopted determinants of innovation potential classification, an analysis of the factors affecting the degree of the innovation (innovation capability) of companies has been conducted.

The study shows that the most important determinants of innovation are managerial competences and labor. In the case of tourism industry, over $80 \%$ of respondents claim to have skilled personnel whose competencies can be used in the process of innovation (innovation competence). Half of the tourism enterprises identify the cooperation in knowledge management, workflow and modern infrastructure as important instruments for innovation. Only one company has taken action in the field of protection of knowledge generated in the organization. The comparative analysis shows that the cooperation and IT tools are better used to create innovations in tourist companies than in the total number of recognized entities.

In the next stage of the analysis the components of the innovation potential are recognized which have got a relatively the greatest impact on the innovation capability. They are considered to be the key determinants of this ability (Table 2).

Table 2. Key determinants of the innovative capability development of tourism industry enterprises

\begin{tabular}{ll}
\hline \multicolumn{1}{c}{ Determinants } & \multicolumn{1}{c}{ Components } \\
\hline Managerial and employee competencies & $\begin{array}{l}\text { Knowledge of foreign languages } \\
\text { Investments in training and the training time } \\
\text { The ability of using modern IT technologies }\end{array}$ \\
\hline Modernity of infrastructure & $\begin{array}{l}\text { Methods of communication within the company } \\
\text { The level of using modern IT infrastructure }\end{array}$ \\
\hline & $\begin{array}{l}\text { Innovation code } \\
\text { Infrastructure to support the decision making process }\end{array}$ \\
& $\begin{array}{l}\text { Rewarding for innovation } \\
\text { Forkflow }\end{array}$ \\
\hline External cooperation on innovation & $\begin{array}{l}\text { Cooperation with the other entities } \\
\text { The number of cooperants }\end{array}$ \\
(knowledge alliances) & Other sources of knowledge \\
\hline Knowledge protection & Knowledge protection clauses \\
\hline
\end{tabular}

Source: own research.

The configuration of the given mechanisms and their influence on both the innovation and performance of the company depends on its characteristics and conditions of operation, e.g. industry, company size, scope of business, etc. 


\section{Categorization of enterprises}

Categorization is a research procedure which aims at establishing a quality level of the company's innovative capability. The categorization of entities has been carried out with regard to their innovation capability level, comparing it to the business innovation. Companies with a low, medium and high level of innovative capability are distinguished. If the company has found that it meets the criteria for only one of the determinants of innovation, then it is assumed to have a low capability for innovation. If a company uses 2 or 3 factors affecting its ability to innovate, it can be concluded that such an enterprise shows the innovativeness at the secondary level. However, if the company has claimed the use of four or more factors among those listed, then we are dealing with a company which belongs to the third category, with a high innovation potential.

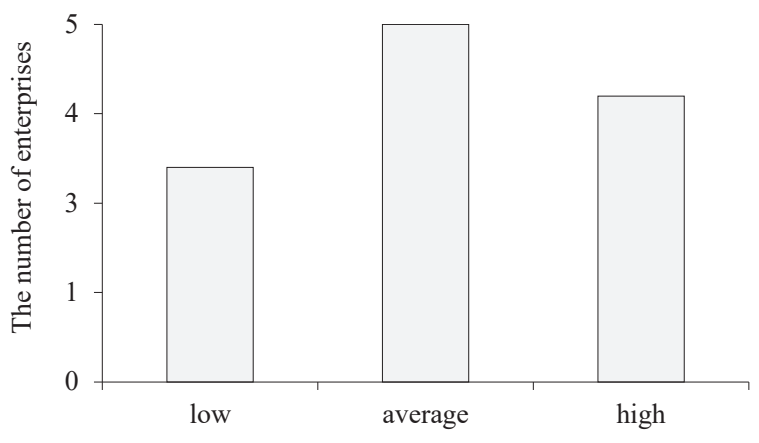

The level of innovativeness capability

Figure 3. Categorization of enterprises according to the level of innovative capabilities

Source: own research.

In the category of companies with a low level of innovation capability 3 tourist companies are placed businesses, 5 companies are characterized by the average level. The innovative capability on the high level is defined in case of 4 companies. During the assessment of the tourism enterprises from the Little Poland Region innovative capability, it has been established that any company, regardless of the level of innovation, is able to create and innovate.

\section{Verification}

Verification involves comparing the qualitative level of the innovative capability of the company (category) with a number of innovations and their generic structure. It tends the thesis that the innovative capacity affects the innovation (innovation) in the form of the number and type of innovation and demonstrate its absence.

The analysis of this data shows that the company has introduced many organizational innovations (innovation 10), followed by marketing (8) and process (8). Also, two innovative 
products have been introduced to companies belonging in to the category of the medium and high innovative capability (Table 3).

Table 3. Number of innovations by the level of innovation capability of tourism businesses

\begin{tabular}{|c|c|c|c|c|c|c|c|}
\hline \multirow{4}{*}{$\begin{array}{l}\text { Type of innovations } \\
\text { conducted }\end{array}$} & \multicolumn{6}{|c|}{ The level of innovativeness capability } & \multirow{4}{*}{$\begin{array}{l}\text { Total number } \\
\text { of innovation }\end{array}$} \\
\hline & \multirow{2}{*}{\multicolumn{2}{|c|}{$\frac{\text { low }}{\text { number of innovation }}$}} & \multirow{2}{*}{\multicolumn{2}{|c|}{$\begin{array}{c}\text { average } \\
\text { number of innovation }\end{array}$}} & \multirow{2}{*}{\multicolumn{2}{|c|}{$\begin{array}{c}\text { high } \\
\text { number of innovation }\end{array}$}} & \\
\hline & & & & & & & \\
\hline & total & 1 entity & total & on 1 entity & total & on 1 entity & \\
\hline Product innovations & 0 & - & 1 & 0.2 & 1 & 0.25 & 2 \\
\hline Process inovatios & 2 & 0.7 & 3 & 0.6 & 3 & 0.75 & 8 \\
\hline Organizational innovations & 2 & 0.7 & 4 & 0.8 & 4 & 1.00 & 10 \\
\hline Marketing innovations & 1 & 0.3 & 3 & 0.6 & 4 & 1.00 & 8 \\
\hline Total & 5 & 1.7 & 11 & 2.2 & 12 & 3.00 & \\
\hline
\end{tabular}

Source: own research.

Comparing the number of the implemented innovations in relation to the number of the companies that form a category, it can be concluded that the high efficiency in innovative activities is characterized by high levels of the company's capacity for innovation (an average of one company accounts for 3 innovations, of which the majority are organizational and marketing innovation). There is also the product innovation. The companies with an average level of the innovation capability introduced a relatively smaller number of innovation than the firms with a high capability for innovation (for 1 person for more than 2 innovation). The tourism businesses categorized as a company with a low level of innovative capabilities have also introduced innovations, however, as not only introduced product innovations. It can be concluded that in the case of tourism enterprises, regardless of their level of innovation ability, development and innovation is possible.

\section{Final remarks and conclusions}

The paper presents a concept-oriented analysis to assess the impact of the innovative capability potential of enterprises on their innovation capability and their innovativeness (innovation performance). Moreover, it describes the procedure for measuring the quality level of innovation capability of enterprises and provides the steps to verify that capability. This analysis can be used, among others, to test the development ability of different objects, i.e. business, industry, region, or the economy. As a specific area of business activity analysis it is the field of research procedure, which aims to assess progress in all or selected areas of the company activities, to program changes and the development of this business.

A new concept of enterprise innovation system has been presented whose essential elements are innovative potential and innovative capability of organizations as determinants of invention and innovation diffusion. This approach towards innovation enables, on the one hand, to assess the progress in all or selected areas of innovation companies, and on the other hand it allows to program and plan its dynamics and shape in accordance with the strategy and business model of 
the organization, with particular consideration on the identified and verified in practice surveyed companies, the key determinant of the innovation capability development (Table 2).

Based on the presented results, one can provide the following conclusions:

- the employee and managerial competences in the field of innovation, and by working in cooperation with clients in the field of knowledge, innovation-oriented organizational culture and the use of IT tools are the essential determinants of the innovative capability development;

- the surveyed companies only marginally use the modern technologies in the process of their employees development (e.g. e-learning), common databases created with the stakeholders (e.g. with customers), pro-innovative forms of work organization (e.g. teamwork) or they use, only to a small extend, the available sources of knowledge (e.g. cooperation with universities, research institutions);

- tourism businesses of the Little Poland region are mainly SME businesses that do not have the capability to conduct research and development activities, and therefore the main source of innovation in these enterprises is the knowledge acquired from other companies or organizations;

- each company is able to innovate, regardless the level of innovative capabilities, even those companies which were characterized by a low level of innovation have also introduced innovations in the process, organization and marketing.

In the light of my own, empirical research results, also taking into consideration the work of predecessors, it is possible to formulate the thesis that companies compete among each other with both created innovations and their innovative capability. The growth of this capability rises to the rank of a primary survival determinant and a development of the company factor. Innovative capability assessment may be useful in determining the competitive and strategic position of enterprises in a given sector.

The literature on the subject emphasizes the importance of innovation in the sector of manufacture, in contrast to the sector of services. In these research, it is assumed that the appropriate resources stimulate innovations in both sectors in different ways, depending on the situation.

For this purpose, the model of relationship between the circumstances and the level of innovative effectiveness of the organization can be used, i.e. the concept of mediating variables (mediators) and regulatory (moderators).

\section{References}

Davenport T.H., Prusak L. Working Knowledge. How Organizations Manage What They Know, Masachusetts 1998.

Hall C.M., Williams A.M., Tourism and Innovation, Routledge, New York 2008.

Hilami M.F., Ramayah T., Mustapha Y., Pawanchik S., Product and Process Innovativeness: Evidence from Malaysian SME's, "European Journal of Social Science” 2010, Vol. 16.

Kozioł L., Wojtowicz A., Karaś A., Postępowanie badawcze ewaluacji zdolności innowacyjnej przedsiębiorstwa, in: Stabilność organizacji we współczesnej gospodarce, eds. M. Cisek, T. Nowogródzka, Studio Emka, Warszawa 2014. 
Pace R., Dipace A., Game-Based Learning and Lifelong Learning for Tourist Operators, in: Cultural Tourism in a Digital Era, ed. V. Katsoni, Springer Proceedings in Business and Economics, Springer International Publishing, Athens 2014.

Pichlak M., Uwarunkowania innowacyjności organizacji. Studium teoretyczne i wyniki badań empirycznych, Difin, Warszawa 2012.

Zastempowski M., Potencjat innowacyjny matych i średnich przedsiębiorstw na tle liderów polskiej gospodarki w świetle badań empirycznych, "International Journal of Contemporary Management" 2013, No. 12 (2).

\section{KONCEPCJA ANALIZY INNOWACYJNOŚCI \\ PRZEDSIĘBIORSTW TURYSTYCZNYCH}

\author{
SŁOWA KLUCZOWE \\ STRESZCZENIE
}

innowacje, potencjał innowacyjny, zdolność innowacyjna, przedsiębiorstwa turystyczne

Celem artykułu jest prezentacja koncepcji analizy ukierunkowanej na ewaluację zdolności innowacyjnej przedsiębiorstwa. Punktem wyjścia dla jej oceny jest potencjał innowacyjny przedsiębiorstw działających w branży turystycznej, w odniesieniu do systemu innowacyjności przedsiębiorstwa. Istotnym narzędziem badawczym jest analiza relacji między zasobami a zdolnościami, która ukazuje związek przyczynowo-skutkowy między tymi kategoriami. Opisano procedurę pomiaru jakościowego zdolności innowacyjnej przedsiębiorstw oraz podano procedurę weryfikacji tej zdolności. W dalszej części artykułu przedstawiono wyniki badań empirycznych nad innowacyjnością 12 przedsiębiorstw turystycznych. Stwierdzono, że kluczowymi determinantami tej zdolności są kompetencje pracownicze i kierownicze w zakresie innowacji, współpraca z kooperantami i klientami w zakresie wiedzy, proinnowacyjna kultura organizacyjna oraz wykorzystywane narzędzia IT. W świetle podanych rezultatów badań własnych empirycznych, jak również wyników badań poprzedników można sformułować tezę, że przedsiębiorstwa konkurują między sobą wykreowanymi innowacjami, jak również zdolnością innowacyjną. Ocena zdolności innowacyjnej może być przydatna w ustalaniu pozycji konkurencyjnej i strategicznej przedsiębiorstw danego sektora. 